\title{
Confessions and denials and the relationship with personality
}

\author{
Gisli H. Gudjonsson'*, Jon Fridrik Sigurdsson², \\ Olafur O. Bragason ${ }^{3}$, Emil Einarsson ${ }^{3}$ and \\ Eva B. Valdimarsdottir ${ }^{3}$ \\ 'Institute of Psychiatry, UK \\ ${ }^{2}$ University Hospital, Reykjavik, Iceland \\ ${ }^{3}$ University of Iceland, Reykjavik, Iceland
}

Purpose. The main aim of the study was to examine the reasons and personality factors associated with confessions and denials. It was hypothesized that antisocial personality traits and active involvement in criminal behaviour would distinguish true confessors and true deniers from false confessors and false deniers.

Method. The participants were I,080 students in further education in Iceland. Each was asked about false admissions made to teachers and parents in the past, as well as about confessions or denials (true and false) made to the police during questioning, and the reasons for having responded in the way they did. The participants also completed questionnaires relating to offending, personality and self-esteem.

Results. One-quarter (25\%) of the participants stated that they had in the past been interrogated by the police in relation to a suspected offence, of whom $59 \%$ said they had confessed. A small minority of those interrogated $(3.7 \%$; $1 \%$ of the total sample) claimed to have made false confessions to the police, whereas $10 \%$ claimed to have made false confessions to teachers or parents. Males were significantly more likely to report false confessions than females. False confessions and false denials were significantly associated with antisocial personality traits, with Eysenck Personality Questionnaire Psychoticism being the single best predictor. Those participants who made true confessions and true denials were most normal in their personality.

Conclusions. Personality is a significant predictor of who makes false confessions and false denials.

*Correspondence should be addressed to Professor Gisli Gudjonsson, Department of Psychology, Institute of Psychiatry, De Crespigny Park, Denmark Hill, London SE5 8AF, UK (e-mail: g.gudjonsson@iop.kcl.ac.uk). 
It is only in recent years that much research has been carried out into the psychological aspects of confessions (Gudjonsson, 2001). Gudjonsson (2003) reviewed five theories of what makes suspects confess to crimes they have committed during police questioning. These, combined with the empirical evidence (Moston, Stephensen, \& Williamson, 1992), suggested that there are three main reasons why suspects confess to crimes they have committed (Gudjonsson \& Sigurdsson, 1999; Sigurdsson \& Gudjonsson, 1996a). These are suspects' perceptions of the strength of the evidence against them, external pressure (e.g. pressure during interrogation, fear of custody) and internal pressure (e.g. wanting to 'clear their conscience'). Usually more than one of these factors are present when suspects confess, but the empirical evidence suggests that it is the perception of the evidence against them that is the most powerful reason for suspects confessing to the offence.

As far as false confessions are concerned, these are psychologically more complicated than true confessions. Kassin and Wrightsman (1985) and Wrightsman and Kassin (1993) suggest three psychologically distinct types of false confession, which they refer to as 'voluntary', 'coerced-compliant' and 'coerced-internalised' types. More recently, Ofshe and Leo (1997a, 1997b) have proposed a modified five-level model which distinguishes between coerced and noncoerced compliant and persuaded confessions. The model, as presented by Ofshe and Leo, applies to both true and false confessions. Gudjonsson (2003) proposes a refined version of the Kassin and Wrightsman original model and recommends two changes. First, the term coerced should be replaced by the term pressured. This overcomes problems related to legal definitions and applications of the term coercion, which are not necessarily used consistently within or across countries. Second, he proposes a bivariate classification system that distinguishes between the three types of false confessions (i.e. voluntary, compliant and internalized) and categorizes the source of pressure (i.e. internal, custodial, noncustodial).

Theories of false confession are largely based on observations of anecdotal cases reported in the literature, or on a series of individual case studies (Gudjonsson, 2003). The empirical literature on false confessions is very limited. Gudjonsson and Sigurdsson (1994) and Sigurdsson and Gudjonsson (1996a, 1996b) carried out research into alleged false confessions among prison inmates. In both studies, $12 \%$ of inmates reported that they had made false confessions to the police sometime in their lives and there were three main reasons given for having made the false confessions: (i) to protect somebody else, (ii) to avoid police pressure, and (iii) to escape police detention. A comparison of the alleged false confessors with other prison inmates showed that the 'false confessors' were significantly more personality disordered, as well as being more actively involved in criminal activity (Sigurdsson \& Gudjonsson, 2001).

As far as denials during interrogation are concerned these have received less research than confessions, although denials have been shown empirically to be associated with weakness of the evidence against the suspect at the time of the interrogation (Moston et al., 1992). In a follow-up study to that carried out by Gudjonson, Clare, Rutter, and Pearse (1993) for the Royal Commission on Criminal Justice, Pearse, Gudjonsson, Clare, and Rutter (1998), found that of a number of psychological and context variables analysed, one predicted a confession and two predicted a denial. The factor that predicted a confession was if the suspect reported having taken illicit drugs within 24 hours of the interrogation. The two factors that predicted a denial were the presence of a solicitor and if the suspect had previously served a prison sentence. Of course, in this police station (field) study it was not possible to distinguish between 
true and false confessions, on the one hand, and true and false denials, on the other hand. This is what brings us to the present study.

From the above discussion, it is evident that when researching confessions and denials during police interrogation it is possible to classify them into four groups (Gudjonsson, 2003): (i) 'true confession' (i.e. the suspect made a true confession to the police), (ii) 'true denial' (i.e. the suspect denies committing an offence of which he or she is innocent or has no memory of committing), (iii) 'false denial' (i.e. the suspect denies an offence he or she committed and recalls committing), and (iv) 'false confession' (i.e. the suspect confesses to an offence he did not commit or the suspect confesses to something of which he or she has no memory).

The purpose of the present study was to investigate differences in the personality and offending behaviour of persons who made confessions or denials when interviewed by the police, according to the four confession-denial categories listed above. Whereas previous research has focused on police detainees (e.g. Gudjonsson et al., 1993; Moston et al., 1992) or prison inmates (Gudjonsson \& Sigurdsson, 1999; Sigurdsson \& Gudjonsson, 1996a, 1997, 2001), the present study involved interviewing representative groups of college students who are known, from our previous research (Gudjonsson \& Sigurdsson, 2004), to have a high level of self-reported offending and some involvement with the police. On the basis of the literature (Gudjonsson, 2003; Sigurdsson \& Gudjonsson, 1996a, 1996b), we hypothesized that those persons who make false confessions to the police are more likely than true confessors and true deniers to: (i) be disordered in their personality (e.g. possessing antisocial personality characteristics), and (ii) have an extensive history of delinquency and offending. We also hypothesized that persons with a history of making false confessions to parents and teachers would be more antisocial in their personality than the other participants, and to be more likely to make false confessions to the police.

\section{Method}

\section{Participants}

The participants were 1,080 students in further education in Iceland. They were from ten colleges in the Great Reykjavik (capital) area and from Akureyri (the largest town in the north of the country). There were 461 (43\%) males and 619 (57\%) females in the study. The average age for the entire sample was 18 years (range 15-25, $S D=1.7$ ). Four further students refused to participate in the study and five provided incomplete forms or questionnaires and were not included in the analysis.

\section{Instruments}

The Eysenck Personality Questionnaire (EPQ; H. J. Eysenck \& Eysenck, 1975; Haraldsson \& Bjornsson, 1985)

This 101-item questionnaire, which has been translated into Icelandic and standardized (Eysenck \& Haraldsson, 1983) measures three main personality dimensions (Psychoticism, Extraversion and Neuroticism) and social desirable response set (Lie Scale).

The Adult Impulsivity, Venturesomeness and Empathy Questionnaire (IVE; H. J. Eysenck \& Eysenck, 1991)

This is a 54-item questionnaire measuring three personality traits, impulsivity, venturesomeness and empathy. 
Gough Socialisation Scale (Gough, 1960; Megargee, 1972)

This 54-item scale is one of the best self-report measures of proneness to antisocial behaviour (Blackburn, 1993) and measures the extent to which individuals have internalized the values of society. The lower the score the more likely the person is to possess antisocial personality traits.

\section{Gudjonsson Compliance Scale (GCS; Gudjonsson, 1989, 1997a)}

This is a 20-item scale that measures the propensity of the person to go along uncritically with requests made by others, largely in order to please others or to avoid conflict and confrontation. The GCS was developed for two different purposes. First, to identify persons who are susceptible to making a false confession under interrogative pressure. Second, those who are susceptible to being pressured into crime by peers and others. It is the first purpose of the GCS which is relevant to the present study.

\section{The Rosenberg Self-Esteem Scale (RSES; Rosenberg, 1965)}

This 10-item scale consists of positive and negative self-appraisal statements rated on a 4-point scale ranging from 'strongly agree' to 'strongly disagree'. Scores range from 10 to 40 with higher scores reflecting low self-esteem.

\section{Self-Reported Delinquency Scale (Mak, 1993)}

This scale consists of 34 items that assesses various delinquent acts. These range from minor antisocial acts (e.g. cheating games machines, truancy from school, drinking alcohol under age in a public place, consuming soft drugs) to more serious acts (e.g. forcing somebody to have sex against their will, using weapons in a fight, setting a fire to damage property, physically assaulting somebody, theft, driving a vehicle whilst intoxicated). The participants are asked to indicate whether they had engaged in any of the delinquent acts in the past 12 months and these make up nine offence domains or subscales. In the present study the nine subscales were not used, because the primary purpose of the study was to focus on the extent of delinquency as measured by the Total Offence Score (TOS) devised by Sankey and Huon (1999). This is based on the seriousness rating of each of the scale's 34 items by judges from different backgrounds (i.e. police officers, teachers, lawyers, psychology students). The mean seriousness score (SS) for each item is then multiplied by the participant's response to each item, giving a range of scores from 0 to 474 . In the present study, a serious offending score (SOS) was also calculated according to formula devised by Sankey and Huon by adding the mean seriousness score for the seven most serious offences (i.e. beating others, weapon fight, force of sex, drink driving, firesetting, burglary and blackmail).

\section{Background, Interrogation and Confession Questionnaire (BICQ)}

The BICQ is a 19-item questionnaire developed specifically for the purpose of this study, which provided background information about each participant, including age, gender, substance abuse problems, false confessions made to teachers and parents, reasons for the false confessions, times spent in a police cell, being interrogated by the police about a suspected offence, the type of offence interrogated about, whether or not he or she committed the offence, with whom the offence was committed, whether there was a confession or a denial made, the main reasons for making a confessions or a denial, giving a false confession to the police during questioning, the reasons for 
making a false confession, and the reason why he or she was being questioned by the police in relation to the false confession.

\section{Procedure}

The participants were approached in class and asked to participate in a study that was concerned with self-reported offending and its relationship with attitudes and personality. The participants were told that their responses were anonymous and confidential. They were tested in scheduled classes, with a maximum of 30 participants being tested in any one class.

The tests were administered in the following order: Mak Self-Reported Delinquency Scale, BICQ, GCS, Gough Socialization Scale, IVE, EPQ and RSES.

\section{Results}

\section{False confessions to teachers and parents}

When asked about past false confessions of wrongdoings (e.g. theft, damage to property) to teachers or parents, $112(10 \%)$ claimed to have made such confessions. There was a significant difference between the males and females $\left(X^{2}=13.3\right.$, d.f. $=1$, $p<.001)$, with $66(14 \%)$ of the males and 46 (7.5\%) of the females stating that they had made false confessions. When asked about the reasons for having made the false confession, 66 (62\%) said they had done it to protect somebody else, $13(12 \%)$ did it due to pressure from teachers, parents or others and eight (7.5\%) said they had been threatened by somebody if they did not do it. Eighteen (17\%) said they could not remember the reason and 12 (9\%) gave other reasons (the total figure exceeds $100 \%$ because some participants gave more than one reason).

In order to investigate the personality factors that are associated with making a false admission to teachers or parents, the two groups (i.e. those who had made admissions vs. those who had not) were compared on the psychometric tests. The results are shown in Table 1. There were significant differences between the two groups on most of the tests, including the EPQ (Psychoticism, Extraversion), the IVE (Impulsivity, Venturesomeness), the Gough Socialisation Scale and the Mak Self-Reported Delinquency Scale (TOS, SOS). A discriminant function analysis of all the tests in Table 1 showed that five of the tests discriminated significantly (Wilks' lambda $=.907$; $F(5,941)=19.23, p<.0001$ ) between the two groups. These were Gough So (Wilks' lambda = .922), Mak TOS (Wilks' lambda = .924), Impulsivity (Wilks' lambda = .917), Mak SOS (Wilks' lambda = .913) and EPQ Lie Score (Wilks' lambda = .911). Therefore, antisocial personality characteristics, impulsivity, and the extent and seriousness of self-reported delinquency were the most discriminating factors between the two groups.

\section{Offending and type of offence}

According to the results of the Mak Self-Reported Delinquency Scale, of the 1,080 college students, 1,050 (93\%) reported that during the previous year they had committed at least one offence as listed within the scale. The mean delinquency scores for the males and females were $77.8(S D=61.2)$ and $48.4(S D=38.3)$ respectively. This difference between males and females was significant $(t=9.65$, d.f. $=1,077$, $p<.001)$. The seriousness scores were $12.1(S D=16.7)$ and $5.9(S D=11.0)$ for males 
Table I. Differences between those who claimed to have admitted to something, which they had not done, to teachers and parents on the psychological tests

\begin{tabular}{|c|c|c|c|}
\hline False confession made & $\begin{array}{c}\text { Yes } \\
n=112 \\
\text { Mean (SD) }\end{array}$ & $\begin{array}{c}\text { No } \\
n=962 \\
\text { Mean }(S D)\end{array}$ & $t$-value \\
\hline \multicolumn{4}{|c|}{ Eysenck Personality Questionnaire: } \\
\hline Psychoticism & $4.0(2.9)$ & $2.6(2.3)$ & $5.63 * * *$ \\
\hline Extraversion & $15.6(3.4)$ & $14.4(4.0)$ & $2.86 * *$ \\
\hline Neuroticism & $12.8(5.2)$ & $12.6(5.0)$ & 0.33 \\
\hline Lie & $9.0(3.8)$ & $9.9(4.3)$ & $-2.17^{*}$ \\
\hline \multicolumn{4}{|c|}{ Eysenck Impulsivity Questionnaire: } \\
\hline Impulsivity & $10.3(4.1)$ & $7.6(4.1)$ & $6.58 * * *$ \\
\hline Venturesomeness & $11.4(3.1)$ & $10.4(3.6)$ & $2.74 * *$ \\
\hline Empathy & I3.I (3.4) & $13.7(3.2)$ & -1.90 \\
\hline Gough Socialisation Scale & $31.6(6.7)$ & $36.2(5.9)$ & $-7.42 * * *$ \\
\hline Gudjonsson Compliance Scale & $8.6(2.9)$ & $8.7(3.2)$ & -0.28 \\
\hline Rosenberg Self-Esteem Scale & I9.1 (5.4) & $18.3(5.4)$ & 1.43 \\
\hline \multicolumn{4}{|l|}{ Self-reported Delinquency Scale: } \\
\hline Total Offending Score & $93.2(73.5)$ & $57.3(46.9)$ & $7.16 * * *$ \\
\hline Serious Offending Score & $12.8(16.7)$ & $8.1(13.7)$ & $3.38 * * *$ \\
\hline
\end{tabular}

$* p<.05, * * p<.01, * * * p<.001$.

and females, respectively. This difference was significant $(t=7.37$, d.f. $=1,077$, $p<.001)$.

Of the total sample, 268 (25\%) said they had been interrogated by the police on one or more occasion in their lives. The interrogation figures for males and females were $174(38 \%)$ and $94(15 \%)$, respectively. The gender difference is significant $(X=71.2$, d.f. $=1, p<.001)$. The great majority $(n=148,55 \%)$ said they had only been interrogated once, 59 (22\%) twice, 57 (21\%) more than twice, and 4 did not state how often they had been interrogated.

The most common types of offence for which the participants had been interrogated by the police were: (i) property offences (31\%); (ii) serious traffic violation (30\%); (iii) criminal damage (29\%), (iv) violent offences (12\%) and (v) drug related offences (9\%). The majority $(76 \%)$ said they had committed the offence in the company of others.

The base rate of guilt for the 268 persons interrogated (i.e. the participant said he or she had committed the offence they were interrogated about), was $67 \%(n=178)$, which means that about one-third of those interrogated denied having committed the offence. The base rate of guilt was $65 \%(n=112)$ for males and $70 \%(n=66)$ for females, respectively. This gender difference is not significant.

\section{Confessions during interrogation}

The confession rate for the 268 persons interrogated was 59\% ( $n=154)$, with the corresponding figures for males and females being 100 (60\%) and 54 (58\%), respectively. There were no significant gender differences with regard to whether the person made a confession during interrogation. 
Table 2. Reasons for making confessions and denials to the police

\begin{tabular}{|c|c|c|c|}
\hline Reasons for confessions & $n(\%)$ & Reasons for denials & $n(\%)$ \\
\hline I believed that the police had proof & $74(52 \%)$ & $\begin{array}{l}\text { I believed that the police } \\
\text { had little proof }\end{array}$ & $14(4 \mid \%)$ \\
\hline $\begin{array}{l}\text { I wanted to get out of the police station } \\
\text { as soon as possible }\end{array}$ & $35(25 \%)$ & $\begin{array}{l}\text { I thought I could get away } \\
\text { with it }\end{array}$ & $12(35 \%)$ \\
\hline I wanted to clear my conscience & $34(24 \%)$ & $\begin{array}{l}\text { I was guilty and feared } \\
\text { the consequences }\end{array}$ & $5(15 \%)$ \\
\hline I was avoiding custody & $12(8 \%)$ & I was ashamed of the offence & $4(12 \%)$ \\
\hline The police pressured me & $7(5 \%)$ & Other reasons & $2(6 \%)$ \\
\hline $\begin{array}{l}\text { I was under the influence of alcohol or } \\
\text { drugs or had withdrawal symptoms }\end{array}$ & $7(5 \%)$ & & \\
\hline Other reasons & $10(7 \%)$ & & \\
\hline
\end{tabular}

The confession rate was 143 (81\%) for the participants who said they had committed the offence.

\section{Reasons for admissions and denials}

Table 2 gives the reasons for making the confessions and the denials during interrogation. In the left column are the reasons given for those who made admissions, and on the right side those who made denials. The main reasons for confessing to the offence were perception of proof (52\%), followed by police or custodial pressure or a desire to get out of the police station (38\%), and the need to clear their conscience (24\%). One-way ANOVA showed significant differences emerged between these three main reasons for making the confession with regard to EPQ Psychoticism $(F=3.4$, d.f. $=2$, $p<.05)$ and IVE Empathy $(F=-3.1$, d.f. $=2, p<.05)$. Thus, high Psychoticism was associated with confessing due to perception of proof, whereas Empathy was highest among those who confessed to clear their conscience.

As far as denials were concerned, the most common reasons for denial were the belief that the police had little proof and that they thought they could get away with the crime.

\section{False confessions}

Of the 154 persons who claimed to have made a confession to the police, 10 (6.5\%) said they had made a false confession. This represents $3.7 \%$ of persons interrogated by the police and $1 \%$ of the entire sample in the study.

The main reason given for making a false confession was that it was done in order to protect somebody else. This was reported as the main reason in six (60\%) of the cases. In the remaining cases the person wanted to avoid police custody $(n=1)$, felt pressured by the police to confess $(n=1)$, was persuaded that he had committed the offence $(n=1)$, and was trying to tease the police $(n=1)$. In none of the 10 cases had the person attended the police station on their own initiative. In all instances they were asked to attend the police station for an interview. In seven (70\%) of the cases the person had been seen in the vicinity of the crime and therefore became a suspect. 
Table 3. The mean and standard deviation scores of the confessors (true and false) and deniers (true and false) on the tests

\begin{tabular}{|c|c|c|c|c|}
\hline Psychological tests & $\begin{array}{l}\text { True deniers } \\
\quad n=68 \\
\text { Mean (SD) }\end{array}$ & $\begin{array}{c}\text { True confessors } \\
n=143 \\
\text { Mean }(S D)\end{array}$ & $\begin{array}{l}\text { False deniers } \\
\qquad \begin{array}{c}n=34 \\
\text { Mean (SD) }\end{array}\end{array}$ & $\begin{array}{c}\text { False confessors } \\
n=10 \\
\text { Mean (SD) }\end{array}$ \\
\hline \multicolumn{5}{|c|}{ Eysenck Personality Questionnaire: } \\
\hline Psychoticism & $3.7(2.4)$ & $3.6(2.8)$ & $4.9(2.9)$ & $7.1(4.5)$ \\
\hline Extraversion & $15.5(3.6)$ & $15.4(3.7)$ & $14.8(3.3)$ & $17.5(2.5)$ \\
\hline Neuroticism & $12.7(5.1)$ & | $2.9(4.7)$ & $13.9(4.9)$ & $11.4(3.9)$ \\
\hline Lie & $8.5(4.0)$ & $8.4(3.8)$ & $7.6(4.1)$ & $8.2(4.7)$ \\
\hline \multicolumn{5}{|c|}{ Eysenck Impulsivity Questionnaire: } \\
\hline Impulsivity & $9.5(4.3)$ & $10.0(4.0)$ & $10.6(3.9)$ & $11.9(4.5)$ \\
\hline Venturesomeness & $11.8(2.8)$ & $11.6(3.0)$ & $11.2(3.2)$ & $1 \mathrm{I} .7(3.5)$ \\
\hline Empathy & $13.0(3.3)$ & $13.2(3.2)$ & $12.4(3.3)$ & $10.9(4.2)$ \\
\hline Gough Socialisation Scale & $33.1(5.9)$ & $31.7(6.2)$ & $29.7(7.0)$ & $29.2(7.1)$ \\
\hline Gudjonsson Compliance Scale & $8.0(2.8)$ & $8.5(3.0)$ & $8.0(2.9)$ & $7.7(3.2)$ \\
\hline Rosenberg Self-Esteem Scale & I8.3 (5.8) & $18.2(5.2)$ & $18.2(5.4)$ & $17.0(3.7)$ \\
\hline \multicolumn{5}{|l|}{ Self-Reported Delinquency Scale: } \\
\hline Total Offending Score & $90.3(58.7)$ & $91.6(60.8)$ & I I $5.0(72.7)$ & $152.7(80.6)$ \\
\hline Serious Offending Score & $17.6(18.3)$ & | $4.1(16.9)$ & $19.5(16.0)$ & $25.5(23.1)$ \\
\hline
\end{tabular}

In two further cases their name had been mentioned by others interviewed by the police.

Eight $(80 \%)$ of the cases of false confessions involved males, who were significantly more likely to make false confession to the police than females $\left(X^{2}=4.35\right.$, d.f. $=1$, $p<.05$, Yates correction).

\section{Differences in personality between the confessors and deniers}

Table 3 gives the mean and standard deviation test scores for the true deniers, true confessors, false deniers and false confessors. In cases where the police had interviewed participants more than once, this classification was based on the reporting of the most recent offence. One-way ANOVA showed significant differences on three of the test scores: Psychoticism $(F=6.4$, d.f. $=3, p<.001)$, Gough Socialisation Scale $(F=2.7$, d.f. $=3, p<.05)$, and Mak TOS $(F=4.2$, d.f. $=3, p<.01)$. Post-hock Sheffé tests showed that the false confessors differed significantly from true confessors on Psychoticism $(p<.01)$ and Mak TOS $(p<.01)$. Similarly false confessors differed significantly from true deniers on Psychoticism $(p<.01)$ and Mak TOS $(p<.01)$.

A discriminant function analysis of all the test scores between true confessors and false confessors showed that two of the test scores, Psychoticism and Extraversion, discriminated significantly between the two groups (Wilks' lambda $=.871 ; F(2,132)=$ $9.74, p<.001$ ), indicating that those who made false confessions were more extraverted and disordered in their personality than true confessors. The individual Wilks' lambda scores for Psychoticism and Extraversion were .975 and .9124 , respectively.

A discriminant function analysis of all the test scores between true deniers and false deniers showed that one of the test scores, the Mak TOS, discriminated significantly between the two groups (Wilks' lambda $=.928 ; F(1,87)=6.86, p<.01$ ). This suggests 
that those respondents who were most actively involved in offending had the greatest tendency to deny their offence.

\section{Discussion}

This is the first study to investigate differences between the four groups: true confessors, true deniers false deniers and false confessors. In particular, no previous study has been able to differentiate true from false deniers. The other advantages of the study are the large sample size of both males and females and the very low refusal rate $(0.4 \%)$, which means that the study is very representative of Icelandic students in further education, the fact that the participants were not assessed in a custodial setting where there might be perceived advantages in their claiming false confessions or denying the offence, and that it was also possible to obtain information about false confessions made to persons other than the police (teachers, parents or others). The main limitation of the study is the reliance on self-report. No official data, such as a police record or a list of previous convictions were obtained for the participants. The other limitation is that the numbers of alleged false confessors is very small (i.e. $n=10$ ) with regard to confessions to the police, although having made false admissions to teachers and parents was over ten times more common $(n=112)$.

The finding that $25 \%$ of the respondents (of the males and females, respectively) reported having been interrogated by the police is consistent with recent research from Scandinavia about the high proportion of persons that are convicted of one or more criminal offence by the age of 30 (Hodgins \& Janson, 2002). The selfreported offending data obtained in the present study are similar to that obtained on a group of Icelandic college students in a previous study (Gudjonsson \& Sigurdsson, 2004).

There are a number of important findings in the present study, which merit a discussion. First, the study provided convincing data that false confessions to wrongdoings to teachers and parents, and to criminal acts during police interrogation do occur. In our prison studies (Gudjonsson \& Sigurdsson, 1994; Sigurdsson \& Gudjonsson, 1996a) the reported rate of false confession during police interrogation was $12 \%$. In the present study the false confession rate was $1 \%$ for the entire population, but $3.7 \%$ for those who had been interrogated by the police. The latter figure can be more meaningfully compared with the $12 \%$ rate among prison inmates. Therefore, it seems that false confessions are almost three times more common among prison inmates than among college students who have been interrogated by the police. The most likely explanation, based on our previous and current findings, is that the more actively the person is engaged in criminal activity, and the more often he or she is interrogated by the police, the greater the likelihood that a false confession is given to the police during questioning. From the present findings, males are significantly more likely than females to have made false confessions to teachers and parents and to the police. The explanation for this gender difference is likely to reflect the greater involvement of males than females in delinquency and criminal acts.

The confession rate of $59 \%$ in the present study is very similar to that found in British studies into confessions among suspects detained at police stations (Gudjonsson, 2003). The relatively high rate of true deniers (i.e. one-third of those interrogated by the police) in the present study emphasizes the importance for the police not to ignore the possibility that they may be interviewing a reasonably high proportion of people who are actually innocent of the crime of which they are accused. 
The reasons the participants gave for having made true confessions to the police are consistent with previous research. The most common reason is the perception of the strength of the evidence against the suspect, which corroborates our previous work (Gudjonsson \& Bownes, 1992; Gudjonsson \& Petursson, 1991; Gudjonsson \& Sigurdsson, 1999) and the important work of Moston et al. (1992). In addition, police or custodial pressure and an internal need to confess are also important in a high proportion of cases.

The finding that confessions arising from the perception of proof are related to EPQ Psychoticism and IVE Lack of Empathy is of both theoretical and practical significance. It supports the view of Inbau, Reid, Buckley, and Jayne (2001) that with 'emotional offenders' it can be effective to appeal to their conscience, whereas 'nonemotional offenders', who according to them often possess antisocial personality disorder, are not troubled by feelings of conscience and the most effective interrogation technique to break down their resistance is to employ a 'factual analysis approach' (i.e. presenting them with common sense arguments about the evidence rather than appealing to their conscience).

The findings on the reasons given for the false admissions to teachers and parents, and false confessions to the police, show that the great majority of false confessions are given, apparently voluntarily, by young people in order to protect somebody else. Relatively few are actually alleged to have resulted from police coercion. Interestingly, in all 10 cases of reported false confession, the person had become a suspect and was therefore being interviewed by the police, rather than their going voluntarily to the police station to confess to the crime.

From the point of personality testing, the findings are clear and consistent. Abnormal personality traits, and particularly high EPQ Psychoticism and poor Socialisation, are highly predictive of who makes false confessions and false denials. In contrast, the two groups with the most normal personality pattern, and the least self-reported history of offending, were true confessors and true deniers. This appears to reflect the differences in the nature of the groups (i.e. true confessions and true denials vs. false confessions and false denials) and their personality (i.e. antisocial personality traits), probably reflecting fundamental differences in the groups' attitudes towards truthfulness and lying. Although those participants who reported having made false confessions were most disordered in their personality, their personality traits, and extent of previous offending history, were consistent with those of false deniers. Both groups appear to tell lies, whether making false confessions or false denials, as a way of coping with a particular predicament. The implication is that both groups may, given the right circumstances and perceived instrumental gains, alternate between making false confessions and false denials. These are overlapping groups who are prepared to lie to the police for their own ends. Whether there is a false confession or a false denial probably depends on the circumstances and perceived gains at the time.

The consistency of Psychoticism as the most discriminating personality variable raises important questions about the nature of this elusive and empirically driven concept. Unlike Extraversion and Neuroticism, Psychoticism was not developed from a wellfounded theoretical base (Blackburn, 1993) and there have been extensive discussions about the nature of Psychoticism, as measured by the EPQ (S. Eysenck, 1997). In his review of Eysenck's theory of criminality (H. J. Eysenck \& Gudjonsson, 1989), Gudjonsson (1997b) discusses the importance of Psychoticism in terms of its relationship with external blame attribution. Psychoticism has been consistently shown to be correlated with offenders blaming their offence on external factors (Gudjonsson, 1984; 
Gudjonsson, Petursson, Sigurdardottir, \& Skulason, 1991; Gudjonsson \& Singh, 1989). Gudjonsson (1997b) interprets this finding as suggesting that emotional coldness and lack of empathy are probably most strongly related to external attribution of blame. In the case of false confessors, and to a lesser extent with false deniers, how does the finding with respect to blame attribution apply to false confessions, if at all?

Gudjonsson and Petursson (1991) studied how the reasons for confessing to crimes were related to blame attribution and found some significant correlations. However, this study does not help us with regard to false confessions. It seems likely that the underlying primary ('lower order') factors of Psychoticism that are relevant to false confessions are made up of a number of factors, such as impulsivity, disregard for the consequences of one's actions, lack of empathy and egocentricity.

Interestingly, in the present study, empathy, as measured by the IVE, did differentiate significantly between true and false confessors, although this difference disappeared after adjusting for the effect of Psychoticism. The lack of empathy of false confessors suggests that the motive for confessing falsely is not based on their confessing for altruistic reasons (i.e. because they genuinely feel for the person who committed the offence and whom they are in the majority of cases protecting). Rather, the motive is likely to be instrumental and self-serving. Future research should focus on understanding the nature of these voluntary false confessions. Interestingly, none of the 10 false confessors reported having been convicted of the offence, which suggests that the police and criminal justice system were able to ensure that no miscarriages of justice followed the false confession.

The findings in this community study corroborate those of Sigurdsson and Gudjonsson (1996a, 1997, 2001) that giving false confessions during interrogations is significantly related to antisocial personality characteristics and criminal lifestyle. It supports the view that the great majority of false confessions, including those given to teachers and parents, are aimed at protecting somebody else rather than resulting from external pressure and coercion. This type of false confession is undoubtedly different from those coerced by the police and where psychological vulnerabilities relating to low IQ, suggestibility, compliance and anxiety are of considerable importance (Gudjonsson, 2003). The main difference between the present community study and the previous prison studies relates to the absence of the influence of compliance in the present study, as measured by the GCS. Of course, one must take into account the small number of alleged false confessors in the present study.

The fact that the study was carried out in Iceland should not limit the importance or the generalizability of the findings. Of course, there are undoubtedly cultural and contextual factors that influence the proportion of confessions and denials within the four groups and the respective base rates. As far as the findings from the personality tests are concerned, and their relationship with confessions and denials, these are undoubtedly generalizable across cultures. Therefore, the present study will hopefully encourage other nations to conduct similar studies and it provides the essential methodology for doing so.

\section{References}

Blackburn, R. (1993). The psychology of criminal conduct. Theory, research and practice. Chichester: Wiley.

Eysenck, H. J., \& Eysenck, S. B. G. (1975). Manual of the Eysenck Personality Questionnaire. London: Hodder and Stoughton. 
Eysenck, H. J., \& Eysenck, S. B. G. (1991). Adult IVE. London: Hodder \& Stoughton.

Eysenck, H. J., \& Gudjonsson, G. H. (1989). The causes and cures of criminality. New York: Plenum Press.

Eysenck, S. (1997). Psychoticism as a dimension of personality. In H. Nyborg (Ed.), The scientific study of human nature. Tribute to Hans J. Eysenck at eighty (pp. 109-121). Oxford: Elsevier Science.

Eysenck, S. B. G., \& Haraldsson, E. (1983). National differences in personality: Iceland and England. Psychological Reports, 53, 999-1003.

Gough, H. G. (1960). Theory and measurement of socialization. Journal of Consulting and Clinical Psychology, 24, 23-30.

Gudjonsson, G. H. (1984). Attribution of blame for criminal acts and its relationship with personality. Personality and Individual Differences, 5, 53-58.

Gudjonsson, G. H. (1989). Compliance in an interrogation situation: A new scale. Personality and Individual Differences, 10, 535-540.

Gudjonsson, G. H. (1997a). The Gudjonsson Suggestibility Scales Manual. Hove, UK: Psychology Press.

Gudjonsson, G. H. (1997b). Crime and personality. In H. Nyborg (Ed.), The scientific study of buman nature. Tribute to Hans J. Eysenck at eighty (pp. 142-164). Oxford: Elsevier Science.

Gudjonsson, G. H. (2001). False confession. The Psychologist, 14, 588-591.

Gudjonsson, G. H. (2003). The psychology of interrogations and confessions. A handbook. Chichester: Wiley.

Gudjonsson, G. H., \& Bownes, I. (1992). The reasons why suspects confess during custodial interrogation: Data for Northern Ireland. Medicine, Science and the Law, 32, 204-212.

Gudjonsson, G. H., Clare, I., Rutter, S., \& Pearse, J. (1993). Persons at risk during interviews in police custody: The identification of vulnerabilities. Royal Commission on Criminal Justice. London: HMSO.

Gudjonsson, G. H., \& Petursson, H. (1991). Custodial interrogation: Why do suspects confess and how does it relate to their crime, attitude and personality? Personality and Individual Differences, 12, 295-306.

Gudjonsson, G. H., Petursson, H., Sigurdardottir, H., \& Skulason, S. (1991). Overcontrolled hostility among prisoners and its relationship with denial and personality scores. Personality and Individual Differences, 12, 17-20.

Gudjonsson, G. H., \& Sigurdsson, J. F. (1994). How frequently do false confessions occur? An empirical study among prison inmates. Psychology, Crime and Law, 1, 21-26.

Gudjonsson, G. H., \& Sigurdsson, J. F. (1999). The Gudjonsson Confession Questionnaire Revised (GCQ-R): Factor structure and its relationship with personality. Personality and Individual Differences, 27, 953-968.

Gudjonsson, G. H., \& Sigurdsson, J. F. (2004). Motivation for offending and personality. Legal and Criminological Psychology, 9, 69-81.

Gudjonsson, G. H., \& Singh, K. K. (1989). The revised Gudjonsson Blame Attribution Inventory. Personality and Individual Differences, 10, 67-70.

Haraldsson, E., \& Bjornsson, J. K. (1985). Íslensk stödlun persónuleikaprófs Eysencks. Félagsvísindadeild Háskóla Íslands.

Hodgins, S., \& Janson, C-G. (2002). Criminality and violence among the mentally disordered. Cambridge: Cambridge University Press.

Inbau, F. E., Reid, J. E., Buckley, J. P., \& Jayne, B. C. (2001). Criminal interrogation and confessions (4th ed.). Gaithersberg, MD: Aspen.

Kassin, S. M., \& Wrightsman, L. S. (1985). Confession evidence. In S. M. Kassin \& L. S. Wrightsman (Eds.), The psychology of evidence and trial procedures (pp. 67-94). London: Sage.

Mak, A. S. (1993). A self-report delinquency scale for Australian adolescents. Australian Journal of Psychology, 45, 107-111. 
Megargee, E. I. (1972). The California Psychological Inventory handbook. London: Jossey-Bass.

Moston, S., Stephenson, G. M., \& Williamson, T. M. (1992). The effects of case characteristics on suspect behaviour during questioning. British Journal of Criminology, 32, 23-40.

Ofshe, R. J., \& Leo, R. A. (1997a). The decision to confess falsely: Rational choice and irrational action. Denver University Law Review, 74, 979-1122.

Ofshe, R. J., \& Leo, R. A. (1997b). The social psychology of police interrogation. The theory and classification of true and false confessions. Studies in Law, Politics and Society, 16, 189251 .

Pearse, J., Gudjonsson, G. H., Clare, I. C. H., \& Rutter, S. (1998). Police interviewing and psychological vulnerabilities: Predicting the likelihood of a confession. Journal of Community and Applied Social Psychology, 8, 1-21.

Rosenberg, M. (1965). Society and the adolescent child. Princeton, NJ: Princeton University Press.

Sankey, M., \& Huon, G. F. (1999). Offence seriousness in adolescent delinquent behaviour. Legal and Criminological Psychology, 4, 253-264.

Sigurdsson, J. F., \& Gudjonsson G. H. (1996a). The psychological characteristics of false confessors'. A study among Icelandic prison inmates and juvenile offenders. Personality and Individual Differences, 20(3), 321-329.

Sigurdsson, J. F., \& Gudjonsson, G. H. (1996b). The relationship between types of claimed false confession made and the reasons why suspects confess to the police according to the Gudjonsson Confession Questionnaire (GCQ). Legal and Criminological Psychology, 1, 259-269.

Sigurdsson, J. F., \& Gudjonsson, G. H. (1997). The criminal history of 'false confessors' and other prison inmates. The Journal of Forensic Psychiatry, 8, 447-445.

Sigurdsson, J. F., \& Gudjonsson, G. H. (2001). False confessions: The relative importance of psychological, criminological and substance abuse variables. Psychology, Crime, and Law, 7, 275-289.

Wrightsman, L. S., \& Kassin, S. M. (1993). Confessions in the courtroom. London: Sage.

Received I 7 July 2002; revised version received 23 December 2002 